\title{
PEMANFAATAN DATA SATELIT GMS MULTI KANAL UNTUK KEGIATAN TEKNOLOGI MODIFIKASI CUACA
}

\author{
Utilization of Multichannel GMS Satellite Data for \\ Weather Modification Technology Activities
}

\author{
Muhamad Djazim Syaifullah $^{1)^{\star}}$, Satyo Nuryanto ${ }^{2)}$ \\ ${ }^{1,2)}$ Balai Besar Teknologi Modifikasi Cuaca - Badan Pengkajian dan Penerapan Teknologi, Gedung Ir. \\ Mohammad Soebagio, GEOSTECH (820), Kawasan PUSPIPTEK, Serpong, Tangerang Selatan \\ ${ }^{*}$ E-mail : djazim.syaifullah@bppt.go.id
}

\begin{abstract}
Intisari
Tulisan ini menyajikan pemanfaatan data satelit GMS (Geostationary Meteorological Satellites) multi kanal untuk informasi perawanan dalam rangka mendukung kegiatan teknologi modifikasi cuaca. Pemanfaatan data satelit meliputi proses pengunduhan data, proses kalibrasi dan visualisasi citra satelit sehingga dapat diinterpretasi. Pemrosesan data satelit juga meliputi jenis dan tipe awan serta ukuran butir awan. Dengan diketahuinya tipe dan jenis awan maka pemilihan target awan dalam pelaksanaan Teknologi Modifikasi Cuaca (TMC) dapat lebih efektif. Data Satelit GMS yang berupa data PGM untuk berbagai kanal telah dimanfaatkan untuk analisis cuaca dan mendukung pelaksanaan kegiatan Teknologi Modifikasi Cuaca (TMC). Dari analisis beberapa kanal Infra Merah (IR) dapat diperoleh tipe/jenis awan dan ukuran butiran awan yang sangat bermanfaat untuk kepentingan Teknologi Modifikasi Cuaca. Diperlukan pengelolaan data yang lebih intensif baik manajemen data maupun kontinuitas pengunduhan data untuk menjamin kelancaran analisis. Selain itu juga diperlukan validasi lapangan misalnya dengan data radar analisis menjadi semakin akurat.
\end{abstract}

Kata Kunci : Satelit GMS, PGM, Multi Kanal, Teknologi Modifikasi Cuaca.

\begin{abstract}
This paper presents the utilization of GMS (Geostationary Meteorological Satellites) multichannel satellite data for cloud cover information in order to support the activities of weather modification technology or cloud seeding. These utilizations covering the process of data downloading, process calibration and visualization of satellite imagery so that it can be interpreted. Processing of satellite data also includes the type of cloud as well as cloud grain size. By knowing the type of cloud, the cloud target selection in the execution of Weather Modification Technology can be more effective. From the analysis of several Infrared (IR) channels can be obtained type/kind of cloud and grain size of the clouds that are beneficial to the interests of cloud seeding. It is required a more intensive data management and continuity of data download. It is also necessary field validation for example with radar data. The purpose of data management was the data processing became more efficient.
\end{abstract}

Keywords : GMS Satellite, PGM, Multichannel, Weather Modification Technology.

\section{PENDAHULUAN}

Teknologi Modifikasi Cuaca (TMC) merupakan usaha manusia untuk meningkatkan curah hujan yang turun secara alami dengan mengubah proses fisika yang terjadi di dalam awan. Proses fisika yang diubah (diberi perlakuan) dengan melakukan penyemaian di dalam awan dapat berupa proses tumbukan dan penggabungan (collision and coalescense) atau proses pembentukan es (ice nucleation). Saat ini TMC menjadi salah satu solusi teknis yang dapat dimanfaatkan untuk menanggulangi bencana yang ditimbulkan oleh karena adanya penyimpangan iklim/cuaca seperti misalnya kekeringan.

Orang kebanyakan berpendapat bahwa sebaiknya penyemaian awan dilakukan pada musim kemarau, ketika air banyak dibutuhkan, sementara itu hujan alam sudah sangat berkurang/tidak ada. Pelaksanaan TMC dengan penyemaian awan pada puncak musim kemarau tidak mungkin diharapkan menghasilkan hujan yang bernilai ekonomis, karena pada periode tersebut awan cumulus sangat terbatas atau tidak ada. Melakukan penyemaian tidak pada kondisi kering atau tidak berawan, untuk mengumpulkan atau mempertahankan cadangan 
air bagi keperluan ke depan melalui tambahan curah hujan atau tambahan aliran sungai yang masuk ke waduk, untuk selanjutnya dikelola, merupakan hal yang lebih baik untuk dilaksanakan dari pada melakukan penyemaian awan pada kondisi kering. Untuk mendapatkan kondisi yang masih dapat diterima informasi perawanan dan cuaca secara umum sangat penting dalam membantu pelaksanaan TMC.

Seiring dengan perkembangan teknologi dalam penginderaan jauh (remote sensing) maka manfaat penginderaan jauh juga semakin besar dan semakin banyak orang yang memanfaatkan penginderaan jauh terutama dalam bidang meteorologi yaitu dengan diluncurkannya satelit meteorologi. Salah satu satelit meteorologi yang terkenal yang peruntukannya untuk analisis cuaca/perawanan adalah Satelit Meteorologi Geostasioner (Geostasioner Meteorology Satelit, GMS).

Data citra satelit GMS mempunyai beberapa kanal inframerah untuk mendeteksi suhu puncak awan, dengan panjang gelombang yang berbeda-beda, sehingga untuk aplikasinya dapat diperoleh beberapa informasi tentang parameter dan karasteristik dari obyek yang terukur (Tahir et al, 2009).

Penelitian mengenai estimasi curah hujan berdasarkan data satelit telah dilakukan di antaranya oleh Vicente (2001), Hong et al. (2006, 2007), dan Naranjo (2007), serta Tahir et al. (2009) Estimasi curah hujan dapat dilakukan berdasarkan suhu awan, dimana pembentukan hujan terjadi pada awan-awan yang mempunyai suhu rendah (Avia et al., 2010, 2013).

Penyajian data yang cepat dan akurat yang diperoleh dari data GMS dapat dilakukan secara cepat (quicklook). Contoh hasil pengolahan seperti ditampilkan di sebuah situs Balai Besar Teknologi Modifikasi Cuaca yang nantinya dapat diakses melalui internet termasuk dari Posko TMC.

Tulisan ini menyajikan pemanfaatan data satelit GMS (Geostationary Meteorological Satellites) multi kanal untuk informasi perawanan dalam rangka mendukung kegiatan teknologi modifikasi cuaca mengkaji kondisi curah hujan dan kondisi cuaca. Pemanfaatan data satelit meliputi proses pengunduhan data, proses kalibrasi dan visualisasi citra satelit sehingga dapat diinterpretasi.

Pemrosesan data satelit juga meliputi jenis dan tipe awan serta ukuran butir awan. Dengan diketahuinya tipe dan jenis awan maka pemilihan target awan dalam pelaksanaan Teknologi Modifikasi Cuaca (TMC) dapat lebih efektif.

\section{METODE}

\subsection{Satelit GMS}

Sistem Satelit Meteorologi Geostasioner
(Geostasioner Meteorologi Satelit, GMS) milik Jepang pada awalnya dikembangkan oleh NASDA didesain oleh GOES Amerika dan sekarang bersama-sama dijalankan oleh NASDA dan Badan Meteorologi Jepang (Japan Meteorologi Agency, JMA). Empat buah pesawat ruang angkasa khusus mengangkut satelit GMS telah diluncurkan sejak tahun 1977, yang terakhir pada bulan September 1989. GMS-3 (Agustus, 1984) diluncurkan sebagai cadangan di posisi $120^{\circ} \mathrm{BT}$, sedangkan GMS-4 terletak di posisi utama pada $140^{\circ} \mathrm{BT}$. Seri terakhir adalah GMS-5 yang diluncurkan oleh penguat $\mathrm{H}$-II pada tahun 1995. GMS-4 adalah wahana angkasa dengan massa sekitar $325 \mathrm{~kg}$, diameter 2,1 $\mathrm{m}$ dan tinggi $3,4 \mathrm{~m}$. Sel surya yang dibawa dapat menghasilkan tenaga sampai $300 \mathrm{~W}$.

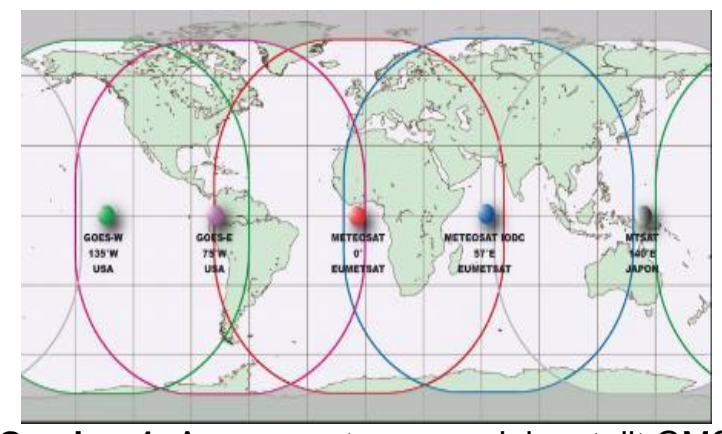

Gambar 1. Area yang tercover oleh satelit GMS (NASDA, 1991).

Sementara itu GMS-5 adalah generasi yang lebih canggih dengan mengunakan instrument canggih VISSR (Visible and Infrared Spin Scan Radiometer) dengan satu kanal cahaya Nampak (visible - 0,55-0,9 $\mu \mathrm{m}$ ) dan tiga kanal inframerah (IR - 10,5-11,5 $\mu \mathrm{m}, 11,5-12,5$ $\mu \mathrm{m}$ dan 6,5-7,0 $\mu \mathrm{m})$. Citra visible dikumpulkan pada rentang kanal 0.50-0.75 $\mu \mathrm{m}$ dengan resolusi $1.25 \mathrm{~km}^{2}$ sedangkan pada citra inframerah mempunyai resolusi $5.0 \mathrm{~km}^{2}$. Diperlukan waktu sekitar 30 menit untuk mendapatkan cakupan penuh yang mengandung 2500 narrow strips.

Satelit GMS mempunyai nama panggilan 'Himawari'. Tabel 1 berikut adalah status dari satelit GMS (Himawari). Beberapa satelit GMS mempunyai posisi dan orbit yang berbeda serta membawa beberapa peralatan dan sensor dengan karasteristik yang berbeda pula seperti disajikan dalam Tabel 2.

Sementara itu Tabel 3 menunjukkan masing-masing spesifikasi kanal imaginer beserta spektrum panjang gelombangnya serta pemanfaatannya.

Sumber data GMS diunduh di situs Homepage Weather Universitas Kochi Jepang, pada alamat situs: http://weather.is.kochiu.ac.jp/archive.html. Data disediakan secara bebas khusus digunakan untuk kegiatan riset akademik dan tujuan pendidikan sekolah. 
Tabel 1. Status dari Satelit GMS (Himawari)

\begin{tabular}{|c|c|c|c|c|}
\hline Nama Satelit & Tgl Peluncuran & Pensiun & Roket Pembawa & $\begin{array}{c}\text { Tempat } \\
\text { Peluncuran }\end{array}$ \\
\hline GMS-1 (Himawari 1) & 14 July 1977 & June 1989 & Delta 2914 & Cape Canaveral \\
\hline GMS-2 (Himawari 2) & 11 August 1981 & November 1987 & N-II (N8F) & Tanegashima \\
\hline GMS-3 (Himawari 3) & 3 August 1984 & June 1995 & N-II (N13F) & Tanegashima \\
\hline GMS-4 (Himawari 4) & 6 September 1989 & February 2000 & H-I (H20F) & Tanegashima \\
\hline GMS-5 (Himawari 5) & 18 March 1995 & July 2005 & H-II (F3) & Tanegashima \\
\hline MTSAT-1 (Mirai 1) & 15 November 1999 & Launch failure & H-II (F8) & Tanegashima \\
\hline MTSAT-1R (Himawari 6) & 26 February 2005 & On standby & H-IIA (F7) & Tanegashima \\
\hline MTSAT-2 (Himawari 7) & 18 February 2006 & Operational & H-IIA (F9) & Tanegashima \\
\hline Himawari 8 & 7 October 2014 & In-orbit & H-IIA (F25) & Tanegashima \\
\hline Himawari 9 & 2016 (Planned) & & TBD & TBD \\
\hline
\end{tabular}

Tabel 2. Karakteristik Spektrum Masing-masing Kanal untuk Beberapa Tipe Satelit GMS.

\begin{tabular}{|c|c|c|c|c|}
\hline & $\begin{array}{l}\text { Himawari -5 } \\
\text { (GMS-5) }\end{array}$ & GOES - 9 & $\begin{array}{l}\text { Himawari-6 (MTSAT- } \\
\text { 1R) / Himawari-7 } \\
\text { (MTSAT-2) }\end{array}$ & $\begin{array}{l}\text { Himawari-8 / } \\
\text { Himawari-9 }\end{array}$ \\
\hline Visible (VIS) & $\begin{array}{c}0.55-0.90 \text { um @ } \\
(1.25 \mathrm{~km} / 6 \mathrm{bits})\end{array}$ & $\begin{array}{c}0.55-0.75 \text { um @ } \\
(1 \mathrm{~km} / 10 \mathrm{bits})\end{array}$ & $\begin{array}{c}0.55-0.90 \text { um @ (1km / } \\
\text { 10bits) }\end{array}$ & $\begin{array}{c}0.47,0.51,0.64^{*} \text { um } \\
@\left(0.5^{*}-1 \mathrm{~km} / \mathrm{bits}\right)\end{array}$ \\
\hline Infrared 1 (IR1) & $\begin{array}{c}10.5-11.5 \text { um @ } \\
\text { (5km/8bits) }\end{array}$ & $\begin{array}{l}\text { 10.2-11.2um @ } \\
\text { (4km/10bits) }\end{array}$ & $\begin{array}{c}\text { 10.3-11.3 um @ (4km / } \\
\text { 10bits) }\end{array}$ & $\begin{array}{c}\text { 10.4, 11.2 um @ } \\
\text { (2km/bits) }\end{array}$ \\
\hline Infrared 2 (IR2) & $\begin{array}{c}11.5-12.5 \text { um @ } \\
\text { (5km/8bits) }\end{array}$ & $\begin{array}{l}\text { 11.5-12.5 um @ } \\
\text { (4km/10bits) }\end{array}$ & $\begin{array}{c}\text { 11.5-12.5 um @ (4km / } \\
\text { 10bits) }\end{array}$ & $\begin{array}{c}\text { 12.4, } 13.3 \text { um @ } \\
\text { (2km/bits) }\end{array}$ \\
\hline Infrared 3 (IR3) & $\begin{array}{c}\text { 6.5-7.0 um @ } \\
\text { (5km/8bits) }\end{array}$ & $\begin{array}{l}\text { 6.50-7.00 um @ } \\
\text { (8km/10bits) }\end{array}$ & $\begin{array}{c}\text { 6.5-7.0 um @ }(4 \mathrm{~km} / \\
10 \mathrm{bits})\end{array}$ & $\begin{array}{c}\text { 6.2, 6.9, 7.3, 8.6, } 9.6 \\
\text { um @ (2km/bits) }\end{array}$ \\
\hline Infrared 4 (IR4) & Not Available & $\begin{array}{l}3.80-4.00 \text { um @ } \\
\text { (4km/10bits) }\end{array}$ & $\begin{array}{c}3.5-4.0 \text { um @ }(4 \mathrm{~km} / \\
10 \mathrm{bits})\end{array}$ & 3.9 um @ (2km/bits) \\
\hline Visible (VIS) & Not Available & Not Available & Not Available & \\
\hline Infrared 4 (IR4) & Not Available & $\begin{array}{l}\text { 3.80-4.00 um @ } \\
\text { (4km/10bits) }\end{array}$ & $\begin{array}{c}3.5-4.0 \text { um @ }(4 \mathrm{~km} / \\
\text { 10bits })\end{array}$ & 3.9 um @ (2km/bits) \\
\hline $\begin{array}{l}\text { Near Infrared } \\
\text { (NIR) }\end{array}$ & Not Available & Not Available & Not Available & $\begin{array}{c}0.86^{*}, 1.6,2.3 \text { um @ } \\
\left(1^{*}-2 \mathrm{~km} / \mathrm{bits}\right)\end{array}$ \\
\hline Frequency & 1 hour & 1 hour & 1 hour & 10 minutes \\
\hline $\begin{array}{l}\text { Position (Eq. / } \\
\text { 35,800km) }\end{array}$ & $140 \mathrm{E}$ & $155 \mathrm{E}$ & $\begin{array}{l}140 \mathrm{E} \text { (MTSAT-2 in } \\
\text { standby at } 145 \mathrm{E} \text { ) }\end{array}$ & $140.7 \mathrm{E}$ \\
\hline
\end{tabular}

Tabel 3. Spesifikasi Kanal Imaginer.

\begin{tabular}{|c|c|c|}
\hline Kanal & $\begin{array}{c}\text { Panjang Gelombang } \\
\text { (MTSAT-1R) / (MTSAT-2) }\end{array}$ & Pemanfaatan \\
\hline Visible (VIS) & $0.55-0.90 \mu \mathrm{m} @(1 \mathrm{~km} / 10 \mathrm{bits})$ & $\begin{array}{c}\text { Memantau kondisi daratan, lautan, dan awan pada siang } \\
\text { hari }\end{array}$ \\
\hline Infrared 1 (IR1) & $10.3-11.3 \mu \mathrm{m} @(4 \mathrm{~km} / 10 \mathrm{bits})$ & $\begin{array}{c}\text { Memantau fenomena meteorologi dan pengamatan } \\
\text { puncak awan }\end{array}$ \\
\hline Infrared 2 (IR2) & $11.5-12.5 \mu \mathrm{m} @(4 \mathrm{~km} / 10 \mathrm{bits})$ & $\begin{array}{c}\text { Memantau fenomena meteorologi dan pengamatan } \\
\text { puncak awan }\end{array}$ \\
\hline Infrared 3 (IR3) & $6.5-7.0 \mu \mathrm{m} @(4 \mathrm{~km} / 10 \mathrm{bits})$ & \begin{tabular}{c} 
Memantau kandungan uap air di awan \\
\hline Infrared 4 (IR4)
\end{tabular} \\
\hline
\end{tabular}

\subsection{File PGM}

Format data dari file citra satelit GMS adalah format PGM. PGM kepanjangan dari Portable Graymap Format. Format PGM ini format file skala keabuan (grayscale) yang paling umum digunakan. Hal ini dirancang untuk menjadi sangat mudah digunakan dalam berbagai aplikasi. Citra PGM menyajikan sebuah gambar grafis dengan skala keabuan. Format PGM memerlukan delapan bit tiap pixel (dengan nilai minimum 0 dan maksimum 255). PGM merupakan citra mentah dengan kompresi tipe lossless. Format PGM merupakan bagian dari PNM (Portable Pixmap File Format). Format ini banyak digunakan untuk aplikasi citra saintifik. Secara umum format PGM ini dideskripsikan sebagai berikut :

1. 'Magic number', sebagai identifikasi tipe file PGM, terdiri dari dua karakter, misal "P2"

2. Jumlah kolom

3. Jumlah baris

4. Nilai maksimum keabuan (0-255), nilai 0 berarti warna hitam, nilai 255 berarti warna putih.

5. Nilai PGM dari skala keabuan, dimulai dari kiri - atas sampai kanan - bawah

Berikut adalah contoh isi dari file dengan format PGM : 
P2

\# feep.pgm

247

15

0000000000000000000000000000000 03333300777700111111110015151515 0

030000007000000110000001500150 033300077700011111100015151515 0

030000000700000001100000001500000 03000000007777700111111110001500000 000000000000000000000000000000

Oleh karena file PGM masih merupakan skala kecerahan maka file tersebut belum mempunyai nilai parameter fisis (misalnya suhu puncak awan), untuk mendapatkan nilai parameter fisis tersebut dilakukan kalibrasi dengan suatu nilai tertentu. Nilai kalibrasi tersebut tersimpan dalam suatu file dengan ekstetion .CAL yang mengiringi masing-masing file PGM tersebut baik untuk kanal IR1, IR2, IR3 maupun kanal IR4. Berikut adalah contoh isi file kalibrasi (.CAL) untuk kanal IR1:

IR1 pixval-temperature conversion table IR1 Temperature of 0 pixval: 329.862000 IR1 Temperature of 1 pixval: 329.547333

IR1 Temperature of 2 pixval: 329.232667

IR1 Temperature of 3 pixval: 328.918000

IR1 Temperature of 4 pixval: 328.603333

IR1 Temperature of 5 pixval: 328.288667

IR1 Temperature of 6 pixval: 327.974000

IR1 Temperature of 7 pixval: 327.659333

IR1 Temperature of 8 pixval: 327.338833

IR1 Temperature of 9 pixval: 327.017500

IR1 Temperature of 10 pixval: 326.696167

IR1 Temperature of 11 pixval: 326.374833

IR1 Temperature of 12 pixval: 326.053500

IR1 Temperature of 13 pixval: 325.732167

IR1 Temperature of 14 pixval: 325.410833

IR1 Temperature of 15 pixval: 325.087931

IR1 Temperature of 16 pixval: 324.762414

IR1 Temperature of 17 pixval: 324.436897

IR1 Temperature of 18 pixval: 324.111379

IR1 Temperature of 19 pixval: 323.785862

IR1 Temperature of 20 pixval: 323.460345

IR1 Temperature of 21 pixval: 323.134828

...

IR1 Temperature of 236 pixval: 202.520000 IR1 Temperature of 237 pixval: 200.948333

IR1 Temperature of 238 pixval: 199.310000

IR1 Temperature of 239 pixval: 197.605000

IR1 Temperature of 240 pixval: 195.833333

IR1 Temperature of 241 pixval: 193.977500

IR1 Temperature of 242 pixval: 192.037500

IR1 Temperature of 243 pixval: 189.990000

IR1 Temperature of 244 pixval: 187.817500

IR1 Temperature of 245 pixval: 185.522500

IR1 Temperature of 246 pixval: 183.065000

IR1 Temperature of 247 pixval: 180.415000

IR1 Temperature of 248 pixval: 177.545000

IR1 Temperature of 249 pixval: 174.385000

IR1 Temperature of 250 pixval: 170.870000

IR1 Temperature of 251 pixval: 166.875000

IR1 Temperature of 252 pixval: 162.215000

IR1 Temperature of 253 pixval: 156.525000

IR1 Temperature of 254 pixval: 149.040000

IR1 Temperature of 255 pixval: 137.305000

Program untuk membaca file citra GMS dengan format PGM adalah dengan membaca

file PGM masing-masing pixel dan kemudian melakukan konversi ke nilai suhu dengan file kalibrasi.

\subsection{Pengunduhan File GMS}

Pengunduhan fileGMS dilakukan setiap jam sekali untuk masing-masing kanal. Proses pengunduhan dilakukan secara otomatis yang dikerjakan oleh komputer, untuk itu perlu dibuat program sederhana atau scriptfile untuk menanganinya. Berikut adalah script untuk melakukan pengunduhan otomatis yang ditulis dengan bash di linux :

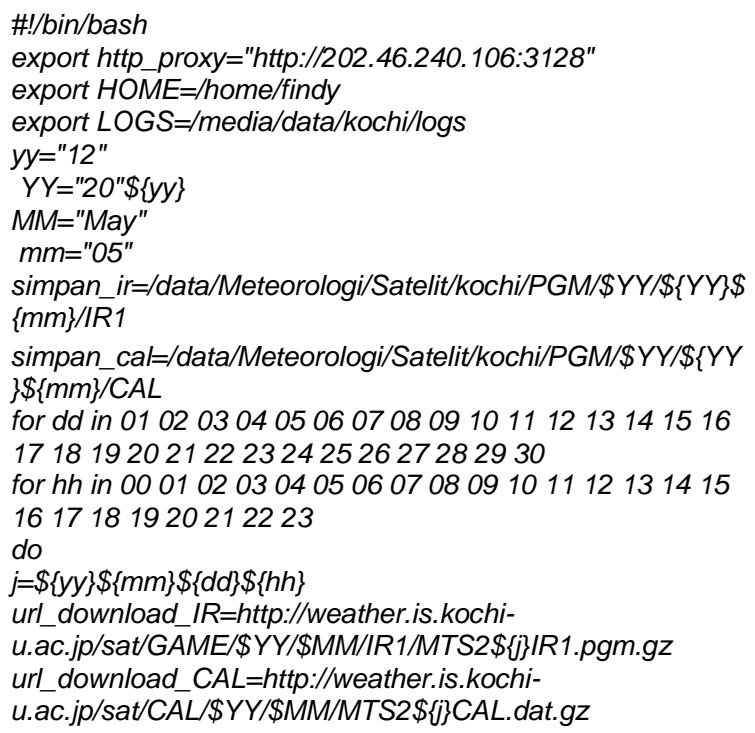


$\$\{L O G S\} / \log p g m$

done

\subsection{Konversi File PGM ke File Grid}

Untuk dapat diolah lebih lanjut, file citra satelit GMS yang berformat PGM haruslah diolah lebih lanjut dengan file kalibrasi untuk menghasilkan file grid yang sudah mempunyai nilai suhu puncak awan.

Berikut adalah contoh script untuk melakukan konversi dari file PGM menjadi file Grid setelah dikonversi dengan file kalibrasi :

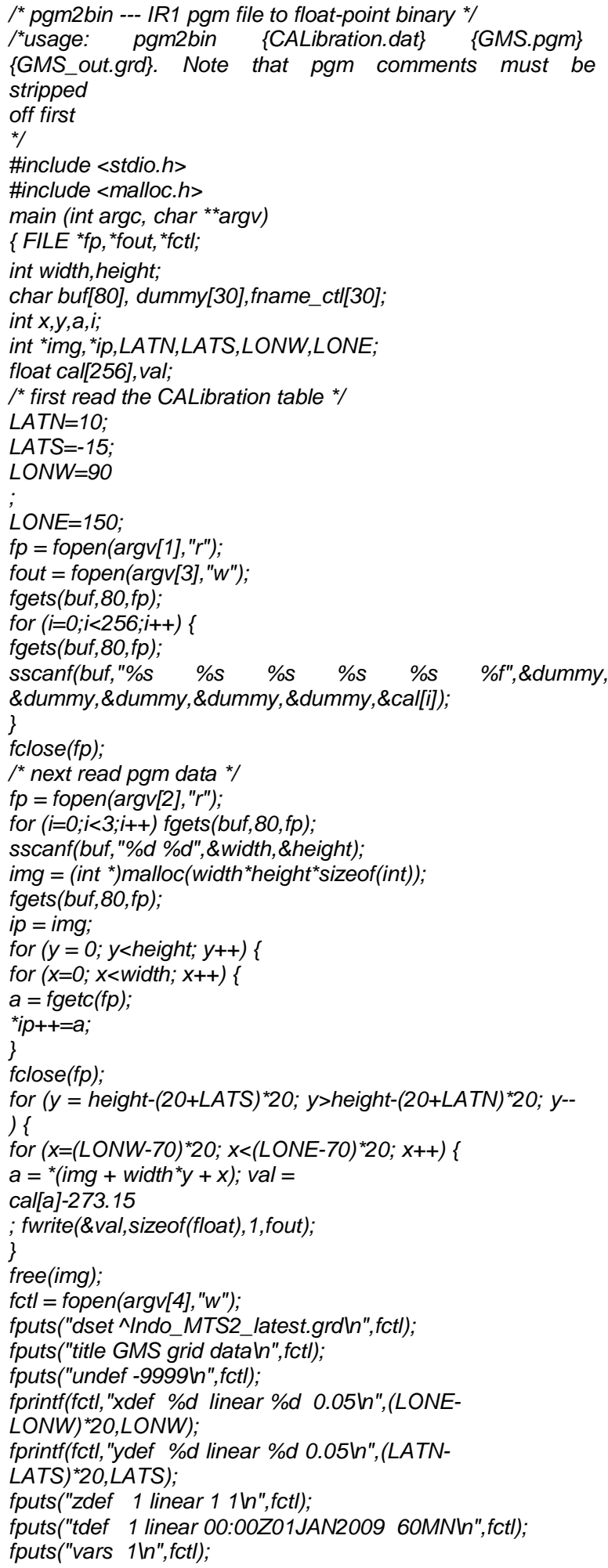

fputs("gms 099 land useln",fctl); fputs("endvars $\mid n ", f c t l)$; fclose (fctl);

\subsection{Control File}

Dalam pengelolaan file citra satelit PGM ini data diolah dengan fasilitas GrADS. GrADS (Grid Analysis and Display System) merupakan software interaktif yang digunakan untuk memanipulasi dan visualisasi data sains kebumian secara mudah, menampilkannya dalam bentuk grafik seperti grafik garis, grafik batang, grafik kontur, grafik kontur berarsir, vektor angin, ataupun garis alur (streamlines), data-data berbentuk grid dan data-data dari stasiun pengamatan. GrADS memiliki versi untuk: Unix, Linux, Windows dan Macintosh.

Macam-macam format data yang bisa dibaca GrADS: netCDF, GRIB (GRldded Binary), HDF-SDS (Hierarchical Data Format Scientific Data Format) dan format biner stream. Grads dapat diperoleh dari internet secara bebas http://grads.iges.org/grads/downloads.html.

Untuk melakukan pengolahan file GRD dengan aplikasi GrADS diperlukan file control yang menerangkan format dan layout dari file binary tersebut sehingga GrADS mampu mengenali dan membacanya. File control berisi informasi tentang alamat (path) dari file binary tersebut, tipe format binary, ukuran horizontal file (latitude, longitude, start, interval), ukuran vertikal file (berapa level ketinggian), ukuran temporal file (interval waktu dan saat waktu mulai), jumlah variable dan nama variable. Berikut adalah contoh file control (.ctl).

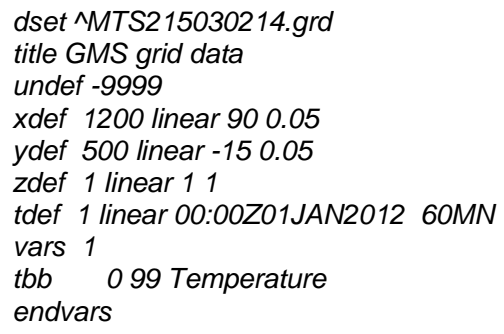

\section{HASIL DAN PEMBAHASAN}

\subsection{Citra Satelit untuk Beberapa Kanal}

Gambar 2, 3, 4 dan 5 merupakan contoh hasil pengolahan citra satelit PGM dengan menggunakan GrADS untuk masing-masing kanal IR1, IR2, IR3 dan IR4.

Dari Gambar 2 yang merupakan citra pada kanal IR1, terdapat puncak awan dengan suhu mencapai $-50^{\circ} \mathrm{C}$ atau pada ketinggian sekitar 40 ribu kaki. Gambar 3 yang merupakan citra pada kanal IR2, terlihat hampir mirip dengan citra pada kanal IR1. Hal ini dikarenakan kanal IR1 dan IR2 mempunyai tapis panjang gelombang yang berdekatan (kanal IR1 
tapis panjang gelombang 10.3-11.3 $\mu \mathrm{m}$, sementara pada kanal IR2 tapis panjang gelombang 11.5-12.5 $\mu \mathrm{m}$ ). Gambar 4 merupakan contoh citra satelit kanal IR3 dengan spectrum panjang gelombang 6.5-7.0 $\mu \mathrm{m}$, tidak banyak informasi yang diberikan kecuali setelah dikombinasikan dengan kanal lain (spektrum panjang gelombang yang lain). Gambar 5 merupakan contoh citra satelit pada kanal IR4 dengan spectrum panjang gelombang 3.5-4.0 $\mu \mathrm{m}$.

I n do n e s i a - IR 1
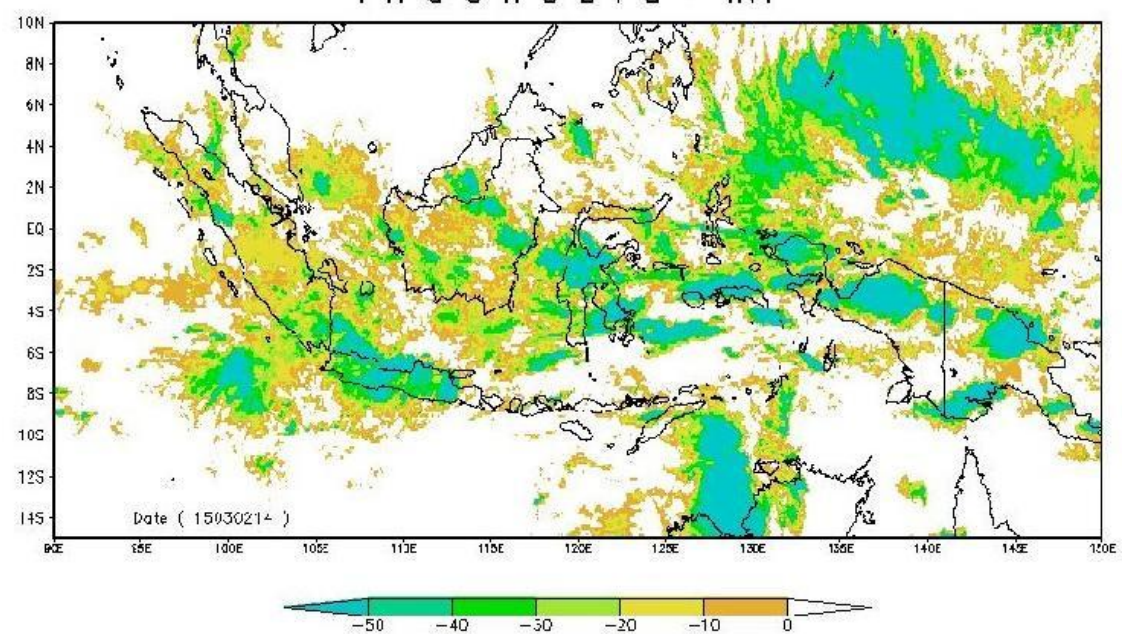

Gambar 2. Contoh citra satelit kanal IR1. (Skala menunjukkan suhu puncak awan $\left({ }^{\circ} \mathrm{C}\right)$ ).

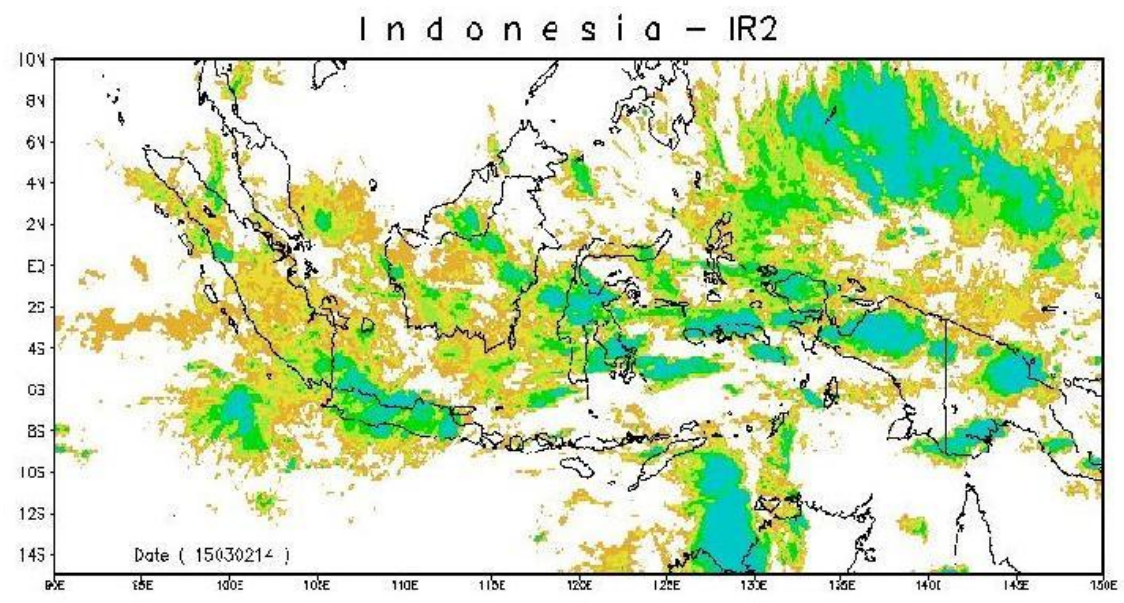

Gambar 3. Contoh citra satelit kanal IR2.

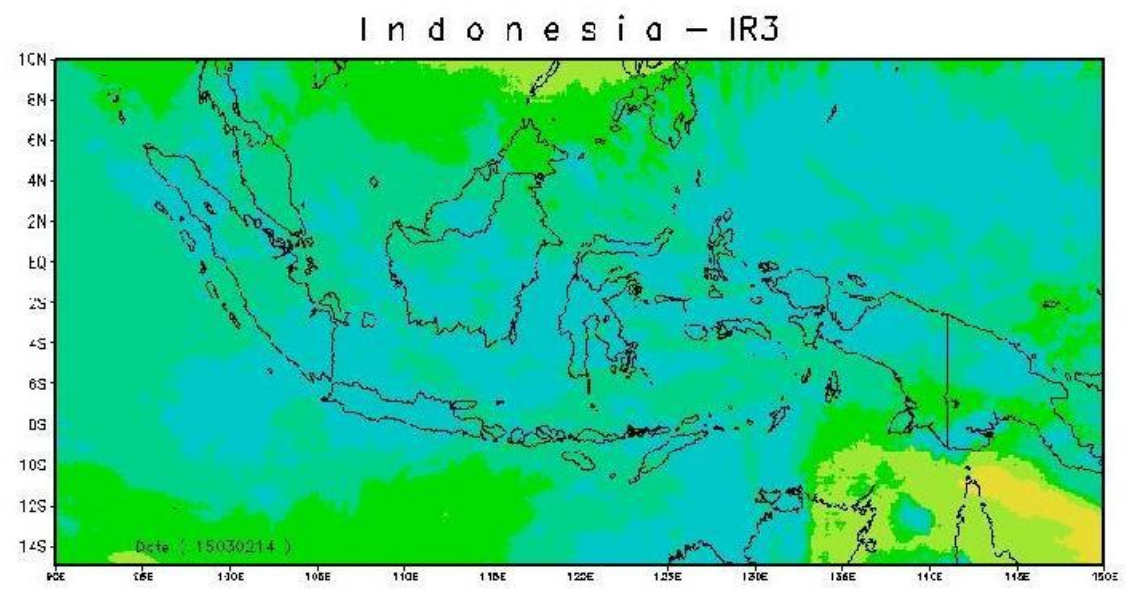

Gambar 4. Contoh citra satelit kanal IR3. 
I ndonesia - IR4

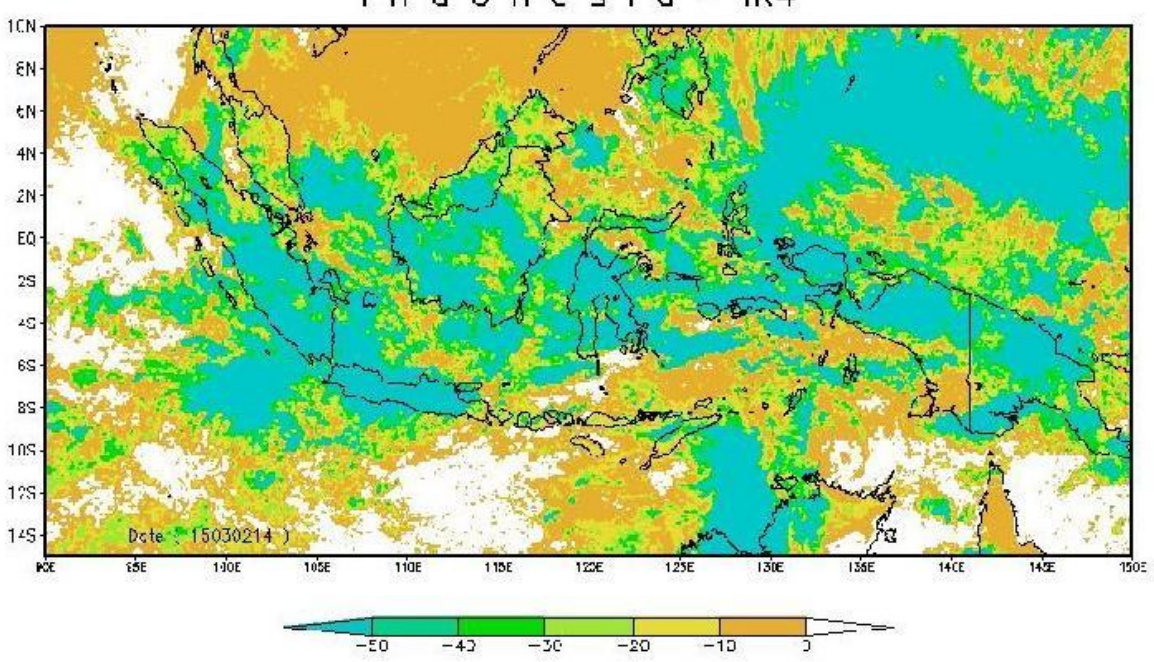

Gambar 5. Contoh citra satelit kanal IR4.

\subsection{Citra Satelit Tipe Awan}

Untuk dapat menentukan jenis ataupun tipe awan diperlukan beberapa konfigurasi kanal infra merah (IR) seperti terlihat pada Tabel 4. Pada kanal IR1 digunakan untuk membedakan antara puncak awan yang tinggi dengan puncak awan yang rendah. Semakin dingin temperatur puncak awan semakin tinggi puncak awan tersebut seperti terlihat pada Gambar 2. Untuk membedakan antara awan Cumulonimbus (Cb) dengan awan Cirrus (awan-awan tipis) diperlukan konfigurasi IR1-IR2. Perbedaan kecil antara kanal IR1 dengan kanal IR2 menunjukkan awan tinggi dan tebal (Cumulonimbus) sedangkan perbedaan yang besar menunjukkan ketiadaan awan atau awan-awan tipis (Cirrus). Untuk membedakan antara awan tebal (Cumulonimbus- $\mathrm{Cb}$ ) dengan awan-awan rendah dan tipis (Stratocumulus-Sc, Humilis) diperlukan konfigurasi IR1-IR3. Perbedaan kecil antara kanal IR1 dengan kanal IR3 menunjukkan awan tebal (Cumulonimbus) sedangkan perbedaan yang besar antara keduanya menunjukkan awan rendah dan tipis (Stratocumulus). Untuk melihat mikrofisis awan (fase, ukuran butir) diperlukan konfigurasi IR4-IR1. Perbedaan besar antara kanal IR4 dengan kanal IR1 menunjukkan awan dengan butir air/es besar, sedangkan perbedaan yang kecil antara keduanya menunjukkan ketiadaan awan atau awan dengan butir air/es kecil.

Gambar 6 berikut adalah contoh citra satelit yang menunjukkan tipe awan dari perbedaan kanal IR1 dengan kanal IR3. Semakin gelap warna menunjukkan ketebalan awan yang semakin tebal dan puncak awan yang tinggi (tipe Cumulonimbus) semakin cerah warna menunjukkan awan yang tipis dan rendah. Sementara Gambar 7 adalah contoh citra satelit yang menunjukkan ukuran butir awan dari perbedaan kanal IR4 dengan kanal IR1, gradasi warna menunjukkan ukuran butir awan, semakin warna gelap semakin besar ukuran butir awan.

Tabel 4. Spesifikasi Kanal Imaginer.

\begin{tabular}{|c|c|l|}
\hline No & Konfigurasi kanal & \multicolumn{1}{|c|}{ Fungsi } \\
\hline 1 & IR1 & $\begin{array}{l}\text { Untuk membedakan antara puncak awan yang tinggi dengan } \\
\text { puncak awan yang rendah. Semakin dingin temperature puncak } \\
\text { awan semakin tinggi puncak awan tersebut. }\end{array}$ \\
\hline 2 & IR1-IR2 & $\begin{array}{l}\text { Untuk membedakan antara awan cumulonimbus dengan awan } \\
\text { cirrus tipis. Perbedaan kecil menunjukkan awan tinggi dan tebal } \\
\text { (cumulonimbus) sedangkan perbedaan yang besar menunjukkan } \\
\text { ketiadaan awan atau awan tipis (cirrus) }\end{array}$ \\
\hline 3 & IR1-IR3 & $\begin{array}{l}\text { Untuk membedakan antara awan cumulonimbus dengan awan } \\
\text { rendah. Perbedaan kecil menunjukkan awan tebal (cumulonimbus) } \\
\text { sedangkan perbedaan yang besar menunjukkan awan rendah dan } \\
\text { tipis (cumulus) }\end{array}$ \\
\hline 4 & IR4-IR1 & $\begin{array}{l}\text { Untuk membedakan mikrofisika puncak awan (fase, ukuran). } \\
\text { Perbedaan besar menunjukkan awan dengan butir air/es besar } \\
\text { sedangkan perbedaan yang kecil menunjukkan ketiadaan awan } \\
\text { atau awan dengan butir air/es kecil }\end{array}$ \\
\hline
\end{tabular}




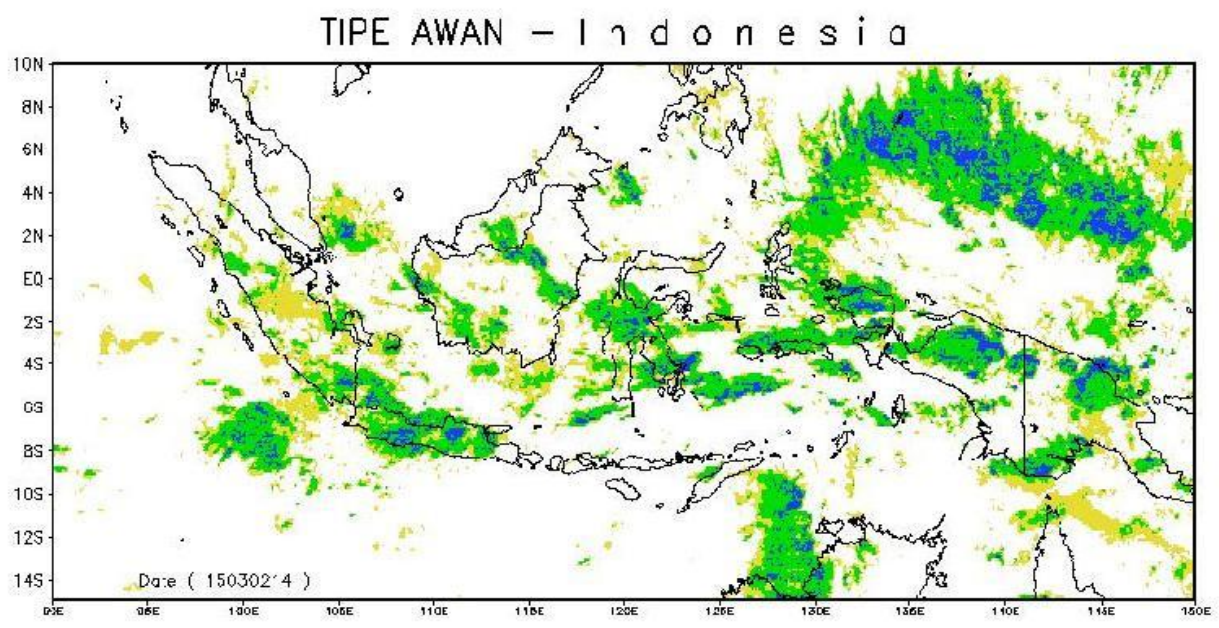

$\ll \infty$ Tipe Awan $\mathrm{Cu} \gg$

Gambar 6. Contoh citra satelit tipe awan (IR1-IR3), gradasi warna menunjukkan tipe awan.

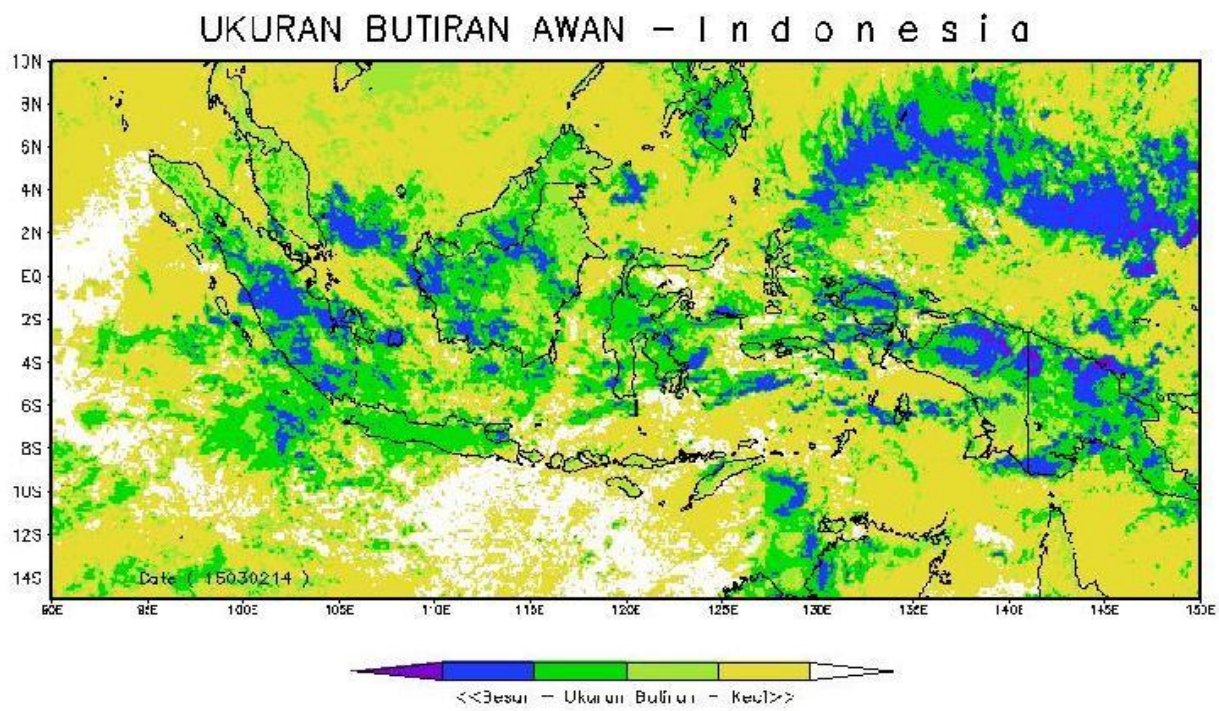

Gambar 7. Contoh citra satelit ukuran butir awan (IR4-IR1), gradasi warna menunjukkan ukuran butir awan, semakin warna gelap semakin besar ukuran butir awan.

Hasil semua proses telah disajikan (diunggah) di situs website Balai Besar Teknologi Modifikasi Cuaca (http://wxmod.bppt.go.id) dan selalu diupdate setiap jamnya.

Gambar 2 s/d Gambar 7 merupakan contoh analisis citra satelit untuk beberapa kanal yang diambil pada tanggal 02 Maret 2015 jam 14 UTC, dari beberapa gambar tersebut dapat dianalisis misalnya untuk wilayah di Pulau Jawa, dengan kanal IR1 (Gambar 2) terlihat hampir seluruh Pulau Jawa tertutupi oleh awan dengan suhu puncak yang dingin (mencapai $-50^{\circ} \mathrm{C}$ ), tetapi jika dilihat dari jenis awannya (Gambar 6) maka awan jenis Cumulonimbus $(\mathrm{Cb})$ hanya terkonsentrasi di perbatasan antara Jawa Tengah - Jawa Barat bagian selatan, Jawa Tengah bagian timur dan sebelah utara wilayah Jakarta, sementara untuk wilayah lain di Pulau Jawa dominan adalah awan Cumulus.

Meskipun demikian dari gambar 7 dapat dilihat bahwa ukuran butiran awan hampir merata dengan ukuran sedang.

\section{KESIMPULAN}

Data Satelit GMS yang berupa data PGM untuk berbagai kanal telah dimanfaatkan untuk analisis cuaca dan mendukung pelaksanaan kegiatan Teknologi Modifikasi Cuaca (TMC).

Dari analisis beberapa kanal Infra Merah (IR) dapat diperoleh tipe/jenis awan dan ukuran butiran awan yang sangat bermanfaat untuk kepentingan Teknologi Modifikasi Cuaca.

Diperlukan pengelolaan data yang lebih intensif baik manajemen data maupun kontinuitas pengunduhan data agar informasi yang disajikan dapat berjalan lancar. Selain itu juga, untuk meningkatkan akurasi analisis, diperlukan pula validasi misalnya dengan data lapangan. 


\section{DAFTAR PUSTAKA}

Avia, L.Q., Haryanto, A. (2013). Penentuan Suhu Threshold Awan Hujan di Wilayah Indonesia Berdasarkan Data Satelit MTSAT dan TRMM. Jurnal Sains Dirgantara, 10(2), 82-89.

Avia, L.Q., Susanti, I., Haryanto, A. (2010). Pengaruh ENSO dan IOD Terhadap Pola Curah Hujan Estimasi Satelit Cuaca GMS/MTSAT di Indonesia. Prosiding Seminar Nasional Sains Atmosfer $I$. Bandung, 26-38.

Hong, Y., Adler, R., Huffman, G. (2006). Evaluation of the Potential of NASA MultiSatellite Precipitation Analysis in Global Landslide Hazard Assessment. Geophysical Research Letters, 33, L22402. doi: 10.1029/2006GL028010

Hong, Y., Adler, R.F., Negri, A., Huffman, G.J. (2007). Flood and Landslide Applications of Near Real-time Satellite Rainfall Estimation. Journal of Natural Hazards, 43(2), 285-294. doi: 10.1007/s11069006-9106-x

Kawamura, H., Qin, H., Sakaida, F., Setiawan, R.Y. (2010). Hourly Sea Surface Temperature Retrieval Using the Japanese Geostationary Satellite, Multi-Functional Transport Satellite (MTSAT). Journal of Oceanography, 66(1), 61-70. doi: 10.1007/s10872-010-0005-0

Maathuis, B.H.P., Gieske, A.S.M., Resios, V., Leeuween, B.v., Mannaerts, C.M., Hendrikse, J.H.M. (2006). Meteosat-8: From Temperatur to Rainfall. ISPRS Technical Commission VII Mid Term Symposium 8-11 May 2006.

Naranjo, L. (2007). Satellite Monitors Rains that
Trigger Landslides. Earth Observatory. NASA.

NASDA. (1991). Geostationary Meteorological Satellite-4 (HIMAWARI-4). Technical Brochure Distributed by NASDA.

Parwati., Suwarsono., Yulianto, F., Suprapto, T. (2009). Penentuan Nilai Ambang Batas untuk Potensi Rawan Banjir dari Data MTSAT dan QMorph (Studi Kasus: Banjir Bengawan Solo 2007). Jurnal Penginderaan Jauh dan Pengolahan Data Citra Digital, 5, 56-63.

Purwalaksana, A.Z., Suaydhi., Waslaluddin. (2015). Otomatisasi dari Hasil Pengamatan Auto Weather Station (AWS) serta Pemanfaatannya dalam Satellite Disaster Early Warning System (SADEWA). Fibusi (JoF), 3(3).

Sagita, N., Prasetya, R. (2013). Analisis Citra Satelit MTSAT dan TRMM Menggunakan Software ER MAPPER, SATAID dan PANOPLY saat Kejadian Curah Hujan Ekstrim di Wilayah Manado 16 Februari 2013. Jurnal Fisika dan Aplikasinya, 9(2), 66-72. doi: 10.12962/j24604682.v9i2.843

Tahir, W., Ibrahim, Z., Ramli, S. (2009). Geostationary Meteorological SatelliteBased Quantitative Rainfall Estimation (GMS-Rain) for Flood Forecasting. Malaysian Journal of Civil Engineering, 21(1), 1-16.

Vicente, G.A. Fernandez-Serdan, J.M., Urunuela, J.J., Rubio, M.A.M., Lobera, P.C. (2001). Satellite Rainfall Estimation for Flash Flood Application: European Basic Auto Estimator Within The Frame of The SAFNWC. Visiting Scientist's Report, Maryland, 1-17. doi: $10.13140 / 2.1 .1380 .6883$ 